\title{
CORRIGENDA
}

Supplement 8, 1976, vol. 52. 'Infant milk powder feeds compared in a common basis' A. E. Mettler.

The author has drawn our attention to the following errors in his manuscript:

\section{Table 6}

Values for P: for $\mathrm{g}$ read mg; Gold Cap SMA S26: values for $\mathrm{Na}+\mathrm{K}$ mEq per litre: for 16.7 read $24 \cdot 2$.
Table 7

Gold Cap SMA S26: values for $\mathrm{Na}+\mathrm{K}$ mEq per litre: for 3.8 read 3.6.

Table 14

For heading 'Sweetness equivalent $\mathbf{g}$ of sucrose per $100 \mathrm{ml}$ ' read 'Sweetness equivalent $\mathrm{g}$ of sucrose per 100 kcal'.

\section{October 1976.}

The author has drawn our attention to an error in his manuscript which was published in the October issue of Postgraduate Medical Journal, 52, page 635 , 2nd line, 2nd word,

\section{for intravenous read intratenons.}

Depot methylprednisolone is a particulate preparation and should never be administered intravenously.

\section{Subject Index} Abetalipoproteinaemia. A case report with patho
logical studies. accessory lobe of liver

Symptomatic -...-- with a review of the literature. acetylsalicylic acid ... April 234

Inhibition of platelet release reaction by -...-. ... February adenocarcinoma

Hypercalcaemia and parathyroid hyperplasia associated with renal -...-. . . . February adrenergic blockade

The effect of ....- in hypertrophic pulmonary osteoarthropathy (HPOA). $\quad$... March

$\beta$-adrenergic blockade

Effects of ..... and stimulation on airways in normal subjects. ... March

$\beta$-adrenoreceptive antagonists

The effect of -...- on the morbidity and mortality in cardiovascular disease. $\quad .$. December

Agranulocytosis and systemic candidiasis following clomipramine therapy. $\quad$... July airway Steroids in -....- diseases (summary).

$$
\begin{array}{cr}
\text { airways disease } & \ldots \text { October } \\
\text { Small -.... } & \ldots \text { April }
\end{array}
$$$$
\text { alcohol and paracetamol }
$$

The effect of desmethylimipramine on the absorption of -...... ... March

Alpha-chain disease in an Englishman.

amoebic liver abscess

$$
\text { ... December } 798
$$

Left lobe -.-.-. ... May

ampulla of Vater

Carcinoid tumour of the .....- associated with

cutaneous neurofibromatosis.

Page ... August
-Carcinoma of the -.-.-- in a haemophiliac patient. ... February

anaemia

Progressive systemic sclerosis and autoimmune haemolytic -.-.-. $\quad$... March angina pectoris

An eighteen months' study of the clinical response to metoprolol, a selective $\beta_{1}$-receptor blocking agent, in patients with ...... . ... August -Medical versus surgical treatment of stable -...-. progress report of a large scale study.

... December

angio-oedema

Familial ..... - a particularly severe form.

anorexia nervosa ... November

Prolactin and gonadotrophin activity in females treated for -...-. . . . February

-Study of EEG sleep characteristics in patients with -...- before and after restoration of matched population mean weight consequent on ingestion of a 'normal' diet. ... January antibody titre

Correlation between anti-DNA -....- and psychiatric manifestations in systemic lupus erythematosus. -Diffuse vasculitis, eosinophilia, and elevated ....- to measles virus. ... May Antidepressant blood levels in acute overdose. anti-DNA antibody ... November 687 Correlation between -..... titre and psychiatric manifestations in systemic lupus erythematosus. ... December 795 antifungal therapy

Combination -...-. for cryptococcal meningitis. ... May 305 